\title{
Neotectonic evolution and sediment budget of the Meuse catchment in the Ardennes and the Roer Valley Rift System
}

\author{
R.T. Van Balen ${ }^{1}$, R.F. Houtgast, F.M. Van der Wateren \& J. Vandenberghe \\ Vrije Universiteit, Faculteit der Aard- en Levenswetenschappen, de Boelelaan 1085, \\ Amsterdam, the Netherlands; e-mail: balr@geo.vu.nl \\ ${ }^{1}$ corresponding author
}

Manuscript received: September 2000; accepted: January 2002

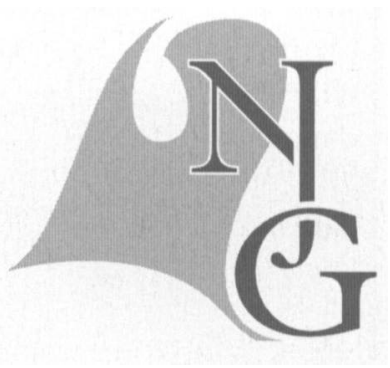

\begin{abstract}
Using marine planation surfaces, fluvial terraces and a digital terrain model, the amount of eroded rock volume versus time for the Meuse catchment has been computed. A comparison of the amount of eroded volume with the volume of sediment preserved in the Roer Valley Rift System shows that $12 \%$ of the eroded volume is trapped in this rift. The neotectonic uplift evolution of the Ardennes is inferred from the incision history of the Meuse River system and compared to the subsidence characteristics of the RoerValley Rift System. Both areas are characterized by an early Middle Pleistocene uplift event.
\end{abstract}

Keywords: Meuse, RoerValley Graben, neotectonics, river terraces, Ardennes, sediment budget

\section{Introduction}

The $33.000 \mathrm{~km}^{2}$ wide rainfed catchment of the Meuse is located in the north-eastern part of the Paris Basin, the Ardennes Massif and the Roer Valley Rift System (Fig.1). Before $\sim 250 \mathrm{ka}$ the Vosges were also part of the upper reaches of the Meuse River system. The Ardennes Massif, and the Rhenish Massif located to the east, belongs to the Variscan orogenic belt. The Mesozoic and Early Tertiary morphotectonic history of the Ardennes has resulted in a number of planation surfaces (Demoulin, 1995a). From the Late Oligocene onwards, the Ardennes were uplifted, and, as a response, an extensive river drainage network developed (Grimbérieux et al., 1995). In the Ardennes, the present-day system was to a large extent established in the Pliocene. During the Plio-Pleistocene the rivers incised and a terrace sequence developed (e.g. Cornet, 1995; Pissart et al., 1997). The terrace staircase of the Meuse River system continues up to the southern border of the RoerValley Graben (Van den Berg, 1996).
The Roer Valley Rift System is located in the southern part of the Netherlands and the north-eastern part of Belgium (Fig.1), north of the Ardennes Massif. The Roer Valley Rift System is part of the Rhine Graben, forming its north-western branch. The Roer Valley Rift System comprises the Campine Block in the south, the Roer Valley Graben in the centre, and the Peel and the Venlo Blocks in the north. The graben is separated from the adjoining blocks by the Feldbiss Fault zone in the south and the Peel Boundary Fault zone in the north, which are the most active faults zones during the Quaternary (e.g. Paulissen et al., 1985; Camelbeeck \& Meghraoui, 1998). A complex Mesozoic history characterizes the Roer Valley Rift System, comprising several rifting and inversion phases (Geluk et al., 1994). A new rifting phase was initiated during the Late Oligocene. This phase is still ongoing, as for example indicated by the earthquakes during historical times (Ahorner et al., 1976; Houtgast, 1992) and recently by the Uden earthquake of 1932 and the 
Roermond earthquake of 1992 (Houtgast, 1992; Van Eck \& Davenport, 1994).

The objective of this paper is to establish the sediment budget of the Meuse river system during the Quaternary and to determine the tectonic control on the evolution of the Meuse in the Ardennes and the Roer Valley Rift System. The boreholes database of TNO NITG/Nuenen has been used to quantify the subsidence history of the Roer Valley Rift System and to estimate the volume of Meuse sediment deposited during the Middle Pleistocene time interval. River terraces are used to determine eroded volumes and neotectonic uplift in the Ardennes. Therefore, terrace correlations of different segments of the Meuse, crossing national borders, have been made (Van Balen et al., 2000). The correlations also provide a chronological framework because all the data on age controls that are available along the different segments of the Meuse (e.g. Van den Berg, 1996; Juvigné \& Renard, 1992; Pissart et al. 1997) are com-

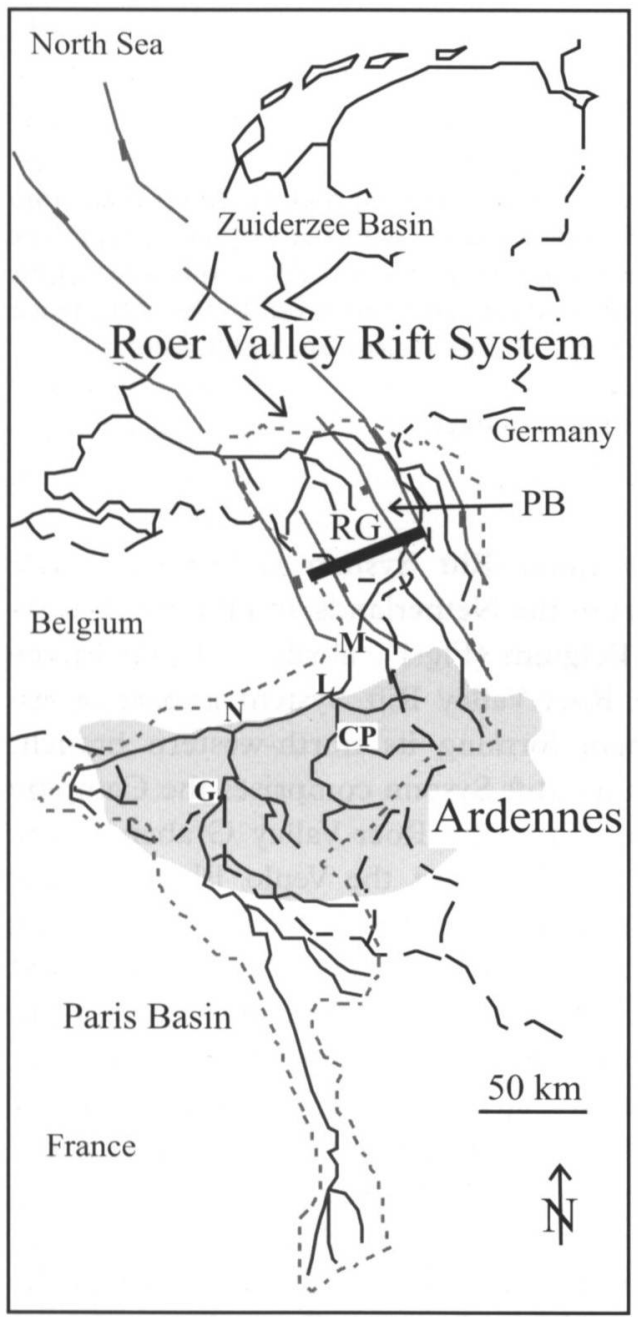

Fig. 1. Catchment of the Meuse river system. $R G=$ Roer Valley Graben, $\mathrm{PB}=$ Peel Block, $\mathrm{M}=$ Maastricht, $\mathrm{L}=\mathrm{Liège}, \mathrm{N}=\mathrm{Namur}$, $\mathrm{G}=$ Givet, $\mathrm{CP}=$ Comblain-au-Pont. The black line indicates the position of the cross-section shown in Fig. 5. bined into one model (Van Balen et al., 2000).

For the terraces, which formed during and before the Middle Pleistocene, the resulting age estimates differ significantly from those estimated by Van den Berg (1996). The main causes for the differences are paleomagnetic data in the Maastricht area (for locations see Fig. 1). According to these data, the Matayuma/Brunhes boundary is located within the youngest part of the Main Terrace sequence. However, paleomagnetic measurements near Liège (Hermée) and Comblain-au-Pont show that the youngest Main Terrace of the Meuse river system is characterized by a normal polarity, which is also the case for the youngest Main Terrace of the Rhine (e.g. Hoselmann, 1996). An age younger than the Matayuma/ Brunhes boundary for the youngest Main Terrace is also in accordance with Ar-Ar dating of volcanic minerals in Rhine terraces (Van Balen et al., 2000).

\section{Sediment budget}

Part of the fluvial deposits located in the Roer Valley Rift System consist of erosion products of the Ardennes. During the Middle Pleistocene, the Veghel Formation was deposited by the Meuse. By comparing the amount of sediment generated by the erosion in the Ardennes and the volume of sediment in the Veghel Formation, an estimate can be given for the amount of sediment that has been transported further downstream, into the North Sea Basin. Furthermore, the eroded volumes can be computed as a function of time with the help of the detailed terrace stratigraphy of the Meuse. This yields insights into the history of the sediment flux.

Using a high-resolution ( 1 data point per $100 \mathrm{~m}^{2}$ ) digital terrain model (DTM), volumes of eroded rock have been calculated in the Meuse catchment. First of all, the total volume of rock eroded in the catchment since the river system was established has been estimated based on the pre-Oligocene planation surfaces identified by Demoulin (1995a). In the DTM, locations were identified where erosion was minimal by selecting those points in the topography that are part of a planation surface. In a second step, a surface was fitted through these points. Next, the volume enclosed by this surface and the actual topography was calculated. The calculated volume of $650 \mathrm{~km}^{3}$ thus represents the total eroded rock volume in the catchment since the Late Oligocene. However, part of the eroded rock volume consists of carbonates. The chemical weathering erosion products, amounting to $70 \mathrm{~km}^{3}$, have not contributed to the sediment fill of the Roer Valley Rift System. This leaves $580 \mathrm{~km}^{3}$. Furthermore, the eroded volume is 
deposited as porous sediment. Therefore, assuming a porosity of $35 \%$, the volume of sediment transported into the Roer Valley Rift System may be estimated at about $890 \mathrm{~km}^{3}$.

The same calculation principle has been applied for determining eroded volumes for several time slices using the terrace stratigraphy. Calculations were made for the six youngest terraces, which have been documented in the Ardennes (T1-T6). Published terrace stratigraphies are available for the Meuse and most of the important tributaries, i.e. the Vesdre, the Ourthe, the Amblève, the Lesse and the Semois. Smaller streams and the Sambre tributary river are lacking in the dataset. The determined eroded volumes, plotted versus time in Fig. 2, therefore underestimate the sediment yield of the total river system. However, the total volume of rock eroded since the Late Oligocene in that part of the drainage area for which the terrace stratigraphies are available equals $180 \mathrm{~km}^{3}$. Possibly a relationship of this sub volume to the total volume, like the ratio $650 / 180$, can be used to calculate the eroded volumes of the total river system from volumes determined from the terrace stratigraphy.

The evolution of eroded volume versus time (Fig. 2) shows a linear trend for the Early Quaternary. The rate of erosion increases during the Middle Pleistocene, and it decreases afterwards. This pattern is similar to the incision history, see below.

Using the boreholes database, the volume of Meuse sediment which was deposited during the formation of the T3 and T2 Meuse Terraces (Veghel Formatie) has been calculated. A simple linear upscaling by the ratio $650 / 180$ has been applied for estimating the amount of generated sediment for the total catchment. Comparison of those two volumes shows that about $12 \%$ of the sediment generated in the Ardennes during this period has been trapped in the RoerValley Rift System.

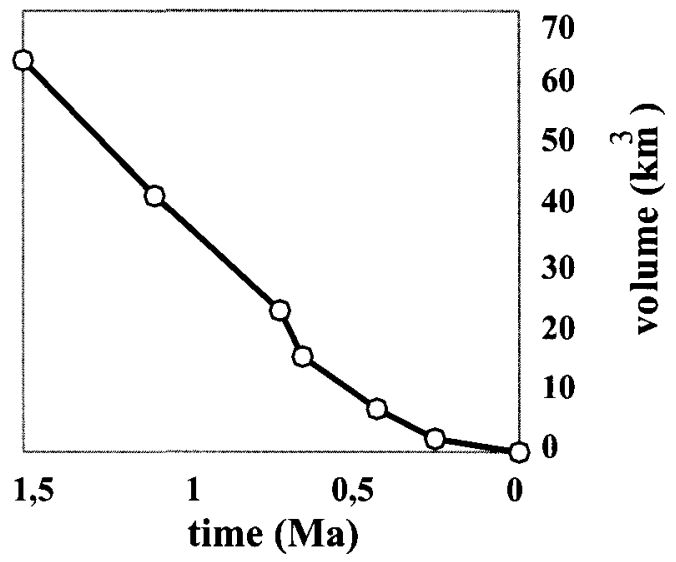

Fig. 2. Eroded volumes versus time determined from the terrace stratigraphy.

\section{Tectonic uplift inferred from the Meuse incision record}

Altitude versus ages diagrams for three locations along the Meuse River are presented in Fig. 3.

Although incision in general can be a response to several processes, like base-level fall, tectonic uplift and climate change, we propose that in this case tectonic uplift is the main cause, and that therefore the incision curves provide an approximation for the tectonic uplift history (Van Balen et al., 2000). One of the reasons why tectonic uplift is the main cause for incision is that the terrace sequence along the Meuse is tectonically deformed. For example, the Middle Pleistocene and older terraces between Namur and Liège dip in the upstream direction (Pissart et al., 1997). This deformation is part of a domal uplift centred at the Eifel volcanic area in the Rhenish Massif, see below.

Fig. 3 shows that incision up to the Middle Pleistocene was linear. It probably reflects the continuation of the tectonic uplift of the Ardennes which started in the Late Tertiary. During the Middle Pleistocene the incision accelerated during a very limited time interval. In the terrace record, the phase of increased incision is represented by the formation of the Middle Terrace sequence. The youngest Main Terrace (T4) was formed just prior to the incision increase. After the acceleration period the incision rate gradually decreased at Namur and Liège, but incision ceased near Givet. This can be attributed to a combination of a decreased tectonic uplift rate and the loss of the Mosel tributary river at $\sim 250 \mathrm{ka}$ (e.g. Pissart et al., 1997).

The mechanism of tectonic uplift during the Middle Pleistocene for the area near Givet can be explained by a local process. Givet is located in the Fagne-Famenne, a $10-15 \mathrm{~km}$ wide shale belt oriented perpendicular to the Meuse. During glacial conditions, large parts of the shales have been eroded by

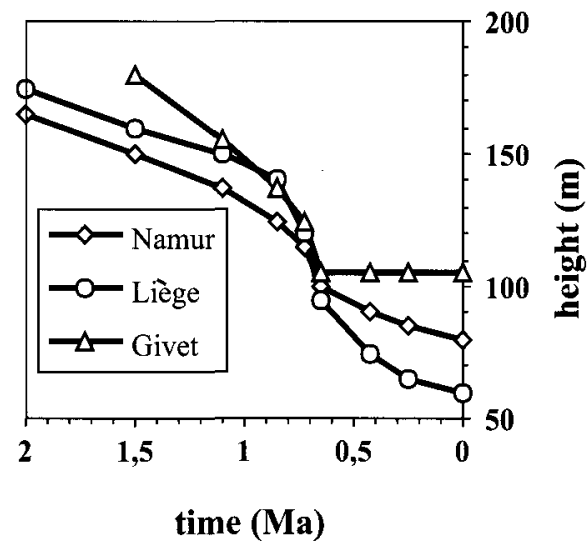

Fig. 3. Incision history for three locations along the Meuse River. 
gelifluction (Pissart, 1974). The average amount of vertical erosion is in the order of $100 \mathrm{~m}$, but locally it is in excess of $150 \mathrm{~m}$. The flexural isostatic response to such an amount of erosion can explain the inferred tectonic uplift near Givet, assuming an effective elastic thickness of the lithosphere of about $2.5 \mathrm{~km}$. However, Demoulin (1995b) questions the terrace stratigraphy near Givet, because terraces along the nearby Lesse and the Tertiary planation surfaces do not show tectonic uplift.

The mechanism for Middle Pleistocene tectonic uplift in the northern part of the Ardennes (Namur, Liège) can not be explained by local processes. In addition, this uplift extended into the Roer Valley Rift System (see below) and is related to uplift of the Rhenish Massif (Meyer \& Stets, 1998; Van Balen et al., 2000). The uplift can be explained by mantle upwelling (Garcia-Castellanos et al., 2000).

\section{Subsidence and tilting of the Roer Valley Rift System}

In order to investigate the subsidence characteristics of the Roer Valley Rift System, six wells have been analysed using backstripping analyses (Houtgast \& Van Balen, 2000). These wells are located on the three different tectonic units of the Roer Valley Rift System. The age control is provided by the chronostratigraphy of Zagwijn $(1989,1996)$.

Fig. 4 shows the resulting subsidence curves. The general trend of these curves is more or less the same. Three subsidence phases can be discriminated. The first phase is a period of relative rapid subsidence starting at the Pliocene-Pleistocene boundary, lasting

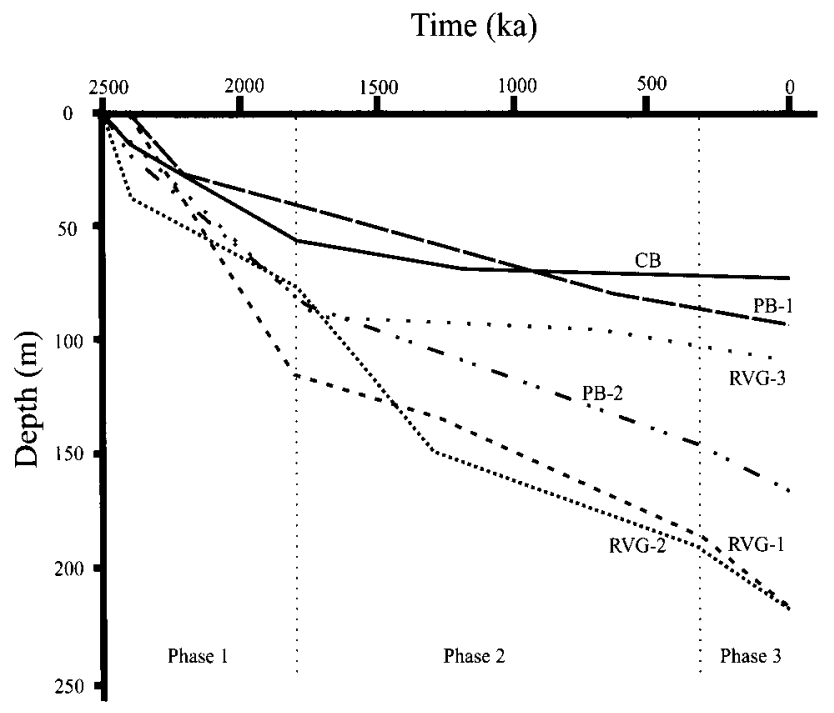

Fig. 4. Subsidence histories for several boreholes in the Roer Valley Rift System. CB = Campine Block, PB = Peel Block, RVG = Roer Valley Graben. until the Late Tiglian (approx. $1800 \mathrm{ka}$ ). The second phase is characterized by relatively slow subsidence, lasting until the Late Pleistocene. Subsidence curves located in the Roer Valley Graben and on the Peel Block show an increased subsidence rate during the third phase, approximately from $\sim 250 \mathrm{ka}$ onwards. This acceleration is not visible in the subsidence curve on the Campine Block, located in the southern part of the Roer Valley Rift System.

Due to the restricted chronostratigraphic resolution in the Roer Valley Rift System the early Middle Pleistocene uplift event can not be identified by the backstripping analysis. However, the event is documented by the changes in the river system, which are contemporaneous with the uplift event in the Ardennes. Prior to the Ardennian uplift event, the Meuse and Rhine rivers both flowed through the central part of the Roer Valley Rift System. During the event, the Rhine flowed north of the Roer Valley Rift System, while the Meuse gradually changed its course to the north, leaving the graben and traversing the Peel Block (e.g. Zagwijn, 1996). Rhine sediments deposited during this time interval (Urk Formation) are the first to contain the volcanic mineral augite derived from the Eifel volcanism. A cross-section through the central part of the Roer Valley Rift System shown in Fig. 5 illustrates this evolution. The behaviour of the Meuse can be explained by northward tilting of the Roer Valley Rift System, combined with increased sediment delivery (Fig. 2), exceeding the subsidence rate. Therefore, we infer that the tectonic uplift documented in the terrace stratigraphy of the Meuse extends into the RoerValley Rift System.

\section{Conclusions}

The total amount of sediments generated by erosion in the Ardennes equals about $890 \mathrm{~km}^{3}$. For the Middle Pleistocene time period, approximately $12 \%$ of the volume of sediments generated by erosion are trapped in the Roer Valley Rift System, the rest is transported further northwards. The neotectonic uplift of the Ardennes as inferred from the fluvial terraces is characterized by an early Middle Pleistocene uplift event. The uplift has a domal distribution and extended into the Roer Valley Rift System. The event is contemporaneous with the onset of the last phase of volcanism in the Eifel area, which is located in the centre of the domal uplift.

\section{Acknowledgements}

We thank M. Geluk (Assen) and an anonymous reviewer for their comments. This study was carried out 


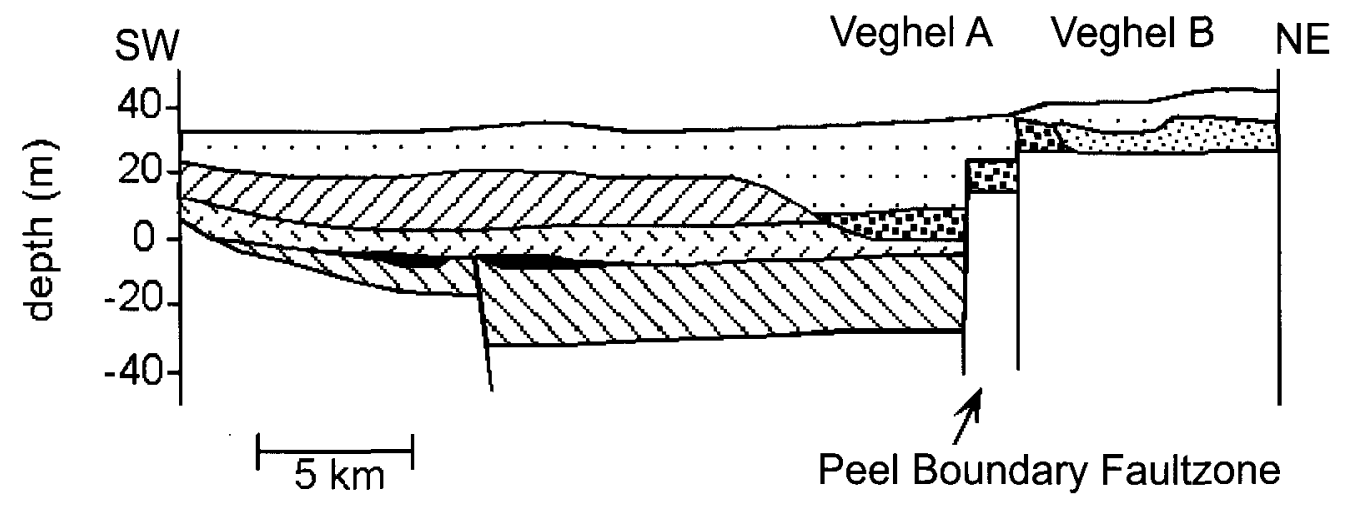

Fig. 5. Cross-section through the Roer Valley Rift System showing the northward younging of fluvial deposits, indicating northward tilting of the Roer Valley Rift System during the Middle Pleistocene (after Zagwijn, 1996).

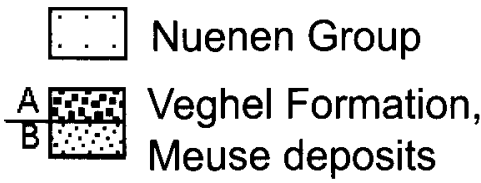

as part of the Netherlands Environmental Earth Systems Dynamics Initiative (NEESDI) funded by the Netherlands Organisation for Scientific Research (NWO).

\section{References}

Ahorner, L., Van Gils, J.M., Flick, J., Houtgast, G. \& Ritsema, A.R., 1976. First draft of the earthquake zoning map of NW Germany, Belgium, Luxembourg and the Netherlands. Kon. Ned. Met. Inst. De Bilt 153: 39-41.

Camelbeeck, T. \& Meghraoui, M., 1998. Geological and geophysical evidence for large palaeo-earthquakes with surface faulting in the Roer Graben (northwest Europe). Geophysical Journal International 132: 347-362.

Cornet, Y., 1995. L'encaissement de rivières ardennaises au cours du Quaternaire. In: Demoulin, A. (ed.): L'Ardenne, essai de géografie physique. Dep. Géogr. Phys. Quat., Univ. Liège: 155-177.

Demoulin, A., 1995a. L'Ardenne des Plateaux, heritage des temps anciens - sufaces d'erosion en Ardenne. In: Demoulin, A. (ed.): L'Ardenne, essai de géografie physique. Dep. Géogr. Phys. Quat., Univ. Liège: 68-93.

Demoulin, A.,1995b. L'Ardenne bouge toujours - neotectonique du massif Ardennais. In: Demoulin, A. (ed.): L'Ardenne, essai de géografie physique. Dep. Géogr. Phys. Quat., Univ. Liège: 110135.

Garcia-Castellanos, D., Cloetingh, S. \& Van Balen, R.T., 2000. Modelling the middle Pleistocene uplift in the Ardennes-Rhenish Massif: thermo-mechanical weakening under the Eifel? Global and Planetary Change 27: 39-52

Geluk, M.C., Duin, E.J.Th., Rijkers, R.H.B., Van den Berg, M.W. \& Van Rooijen, P., 1994. Stratigraphy and tectonics of the Roer Valley Graben. Geologie en Mijnbouw 73: 129-141.

Grimbérieux, J., Laurant, A. \& Ozer, P., 1995. Les rivières s'installent. In: Demoulin, A. (ed.): L'Ardenne, essai de géografie physique. Dep. Géogr. Phys. Quat., Univ. Liège: 94-109.

Haq, B.U., Hardenbol, J. \& Vail, P., 1987. Chronology of fluctuating sea levels since the Triassic. Science 235: 1156-1167.

Hoselmann, C., 1996. Der Haupterrassen-Komplex am unteren Mittelrhein. Zeitschrift Deutsche Geologische Geselschaft 147: 481-497.
Houtgast, G., 1992. Catalogus van aardbevingen in Nederland $t / m$ 1990. Koninklijk Nederlands Meteorologisch Instituut. De Bilt 179: 166 pp.

Houtgast, R.F. \& Van Balen, R.T., 2000. Neotectonics of the Roer Valley Rift System, the Netherlands. Global and Planetary Change 27: 131-146.

Juvigné, E. \& Renard, F., 1992. Les terrasses de la Meuse de Liège à Maastricht. Annales société géologique de Belgique 115: 167186.

Meyer, W. \& Stets, J., 1998. Junge Tektonik im Rheinischen Schiefergebirge und ihre Quantifizierung. Zeitschrift Deutsche Geologische Geselschaft 149: 359-379.

Paulissen, E., Vandenberghe, J., \& Gullentops, F., 1985. The Feldbiss fault in the Maas Valley bottom (Limburg, Belgium). Geologie en Mijnbouw 64: 79-87.

Pissart, A., 1974. La Meuse en France et en Belgique. Formation du basin hydrographique. Les terrasses et leur enseignements, In: Macar, P. (ed.): L'évolution quaternaire des basins fluviaux de la mer du nord mérondiale. Centenaire de la société géologique de Belgique, Liège: 105-131.

Pissart, A., Harmand, D. \& Krook, L., 1997. L'evolution de la Meuse de Toul à Maastricht depuis le Miocène: corrélations chronologiques et traces des capturesde la Meuse Lorraine d'après les minéraux denses. Géographie physique et Quaternaire 51: 267-284.

Van Balen, R.T., Houtgast, R.F., Van der Wateren, F.M., Vandenberghe, J. \& Bogaart, P.W., 2000. Sediment budget and tectonic evolution of the Meuse catchment in the Ardennes and the Roer Valley Rift System. Global and Planetary Change 27: 113-129.

Van Eck, T. \& Davenport, C.A., 1994. Seismotectonics and seismic hazard in the Roer Valley Graben: an overview, Geologie en Mijnbouw 73: 95-98.

Van den Berg, M.W., 1996. Fluvial sequences of the Maas - a 10 Ma record of neotectonics and climate change at various timescales. Ph.D-thesis, Agricultural University, Wageningen: $181 \mathrm{pp}$.

Zagwijn, W.H., 1989. The Netherlands during the Tertiary and Quaternary: a case history of coastal lowland evolution. Geologie en Mijnbouw 68: 107-120.

Zagwijn, W.H., 1996. The Cromerien Complex Stage of the Netherlands and correlation with other areas in Europe. In: Turner, C. (ed.): The early Middle Pleistocene in Europe. Proc. SEQS Cromer symposium, Balkema (Rotterdam): 145-172. 